\title{
Sentinel lymph node biopsy in patients with locally advanced breast cancer after neoadjuvant chemotherapy ${ }^{1}$
}

\author{
Biopsia do linfonodo sentinela em câncer na mama localmente avançado pós-quimioterapia \\ neoadjuvante
}

\section{Paulo Henrique Walter Aguiar ${ }^{\mathrm{I}}$, Luiz Gonzaga Porto Pinheiro ${ }^{\mathrm{II}}$, Rosa Maria Salani Mota ${ }^{\mathrm{III}}$, Nair Hermínia Gurjão Margotti ${ }^{\mathrm{IV}}$, João Ivo Xavier Rochav}

IMaster, Department of Mastology, Walter Cantidio University Hospital and Assis Chateaubriand Maternity School, UFC, Fortaleza-CE, Brazil. Acquisition and interpretation of data, involved with technical procedures, manuscript writing.

IIPhD, Associate Professor, Department of Surgery, Faculty of Medicine, UFC, Fortaleza-CE, Brazil. Design of the study, analysis and interpretation of data, critical revision.

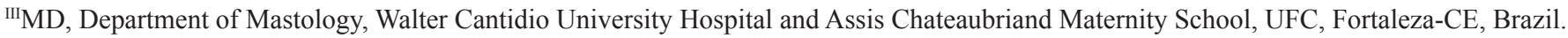
Acquisition of data, helped with technical procedures.

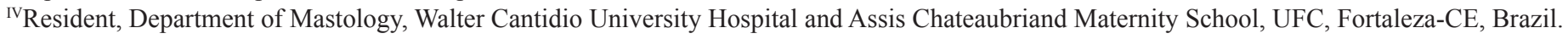
Acquisition of data, manuscript preparation.

${ }^{\mathrm{v}}$ Graduate student, Faculty of Medicine, UFC, Fortaleza-CE, Brazil. Acquisition of data, statistical analysis, manuscript preparation.

\begin{abstract}
PURPOSE: To check the rate of sentinel lymph node (SLN) identification in patients with locally advanced breast cancer who underwent neoadjuvant chemotherapy comparing intraoperative contact cytology (imprint) and embedded in paraffin and validation of methods.

METHODS: A cross-sectional validation of diagnostic test involving 34 patients from the outpatient clinic of the Maternity School Assis Chateaubriand. The patients had locally advanced breast cancer and were treated with neoadjuvant chemotherapy. Those with clinically negative axilla underwent SLN biopsy, studied by imprint and histopathology in paraffin. All patients underwent axillary dissection and its histopathological study.

RESULTS: The SLN identification rate was $85.3 \%$ (29/34). The sensitivity of imprint associated with paraffin on detection of metastasis compared to histopathology of the axillary content was $84.62 \%$ and specificity of $100 \%$ with false-negative rate of $12.01 \%$ and an accuracy of $92.77 \%$.
\end{abstract}

CONCLUSION: The search for metastases in the SLN by imprint and histopathological analysis in paraffin compared to the gold standard (axillary dissection) had a low sensitivity with high rate of false negatives in our sample.

Key words: Sentinel Lymph Node Biopsy. Breast Neoplasm. Neoadjuvant Therapy.

\section{RESUMO}

OBJETIVO: Verificar a taxa de identificação do linfonodo sentinela (LS) em pacientes portadoras de câncer na mama localmente avançado e que foram submetidos à quimioterapia neoadjuvante comparando a citologia de contato intraoperatória (imprint) e a inclusão em parafina e validação dos procedimentos.

MÉTODOS: Estudo transversal de validação de teste diagnóstico envolvendo 34 pacientes oriundas do Ambulatório da MaternidadeEscola Assis Chateaubriand. As pacientes eram portadoras de câncer na mama localmente avançado e foram tratadas com quimioterapia neoadjuvante. Àquelas com axila clinicamente negativa foram submetidas à biopsia do LS, esse estudado por impint e histopatologia em parafina. Todas as pacientes foram submetidas a esvaziamento axilar e seu estudo histopatológico.

RESULTADOS: A taxa de identificação do LS foi de 85,3\% (29/34). A sensibilidade do imprint associada à parafina quanto à detecção de metástase comparado a análise histopatológica do conteúdo axilar foi de 84,62\% e a especificidade de $100 \%$ com taxa de falsonegativo de $12,01 \%$ e acurácia de $92,77 \%$.

CONCLUSÃO: A pesquisa de metástases no linfonodo sentinela por imprint e análise histopatológica em parafina quando comparado ao padrão ouro (esvaziamento axilar) apresentou baixa sensibilidade com taxa elevada de falsos negativos em nossa amostra.

Descritores: Biópsia de Linfonodo Sentinela. Neoplasias da Mama. Terapia Neoadjuvante. 


\section{Introduction}

In Brazil, breast cancer is the malignancy that causes more deaths among women ${ }^{1}$. There is an increase of their frequency in developed and developing countries, with a 10 times increase in incidence rates according to World Health Organization ${ }^{2}$.

Unlike to developed countries where screening mammography showed an impact on overall survival, among us, most cases are diagnosed in an opportunistic way with over $50 \%$ in advanced stages of disease (clinical stage III and IV), factor that provides a lower rate of curability and higher mutilation ${ }^{3}$.

A review study of SLN biopsy in patients with breast cancer showed an accuracy of $95 \%$, which proposes reliability and safety of the method ${ }^{4}$.

The chemotherapy as adjuvant treatment in breast cancer has been used in different settings. Chemotherapy neodjuvante (used before the surgical procedure) may benefit the patients, resulting in decreased tumor and axillary status and higher conversion rate of mastectomies in conservative surgery ${ }^{5}$.

There is an association between tumor response to neodjuvante therapy and the determination of lymph node status in patients undergoing primary chemotherapy. Women with pathologic complete response, had more often negative lymph nodes $(87 \%)$, while the proportion of patients with negative lymph nodes decreases with lower tumor response to chemotherapy ${ }^{5}$.

With the reduction of positive lymph nodes in the axilla after neoadjuvant chemotherapy, the axillary dissection in some patients is questioned. The lymphatic mapping and sentinel node biopsy can be used to identify those patients who could benefit from the use of the method. This possibility has led many services to design researches in order to validate the technique of sentinel node biopsy in patients undergoing neoadjuvant chemotherapy.

One of the questions on the implementation of the SLN biopsy in patients undergoing neoadjuvant chemotherapy is the possibility to cause histological changes in lymph nodes as areas of fibrosis, fat necrosis, histiocytosis and granulation tissue that can compromise the SLN identification rate and provide more false-negative ${ }^{6}$.

For the above reasons, it is imperative establish the feasibility and accuracy of sentinel node biopsy after neoadjuvant chemotherapy in order to identify patients who might have preserved the armpit. The technique, therefore, is feasible; however the clinical significance in the long term is unclear. The majority of patients affected with breast cancer presents at an advanced stage. Still, some of them might be helped by the introduction of the method, which is already signed in operable breast cancers and appears as a possible alternative for patients who receive neoadjuvant chemotherapy. The applicability of the method however is still obscured by the limited literature and much work is needed to substantiate it.

\section{Methods}

It was a sectional study performed to validate a diagnostic test in which we evaluated 34 patients with breast cancer from the Department of Mastology, Walter Cantidio University Hospital and Assis Chateaubriand Maternity School, Federal University of Ceará in the period of 2004 to 2006 and who was referred for neoadjuvant chemotherapy. Each patient enrolled in the study was assessed and data were recorded in a specific form.

We included patients with breast cancer aged between 18 and 75 years, histologically diagnosed by core biopsy, incisional or excisional biopsy, in stage II, III or IV and who had clinically negative axilla after neoadjuvant chemotherapy. Our patients received at least one cycle of preoperative chemotherapy with some type of clinical response, hormone receptor status are not specified. They made chemotherapy with FAC, FEC, AC or AC-T (fluorouracil $500 \mathrm{mg} / \mathrm{m}^{2}$, doxurrubicina $50 \mathrm{mg} / \mathrm{m}^{2}$, cyclophosphamide $500 \mathrm{mg} / \mathrm{m}^{2}$, epirubicin $60 \mathrm{mg} / \mathrm{m}^{2}$, paclitaxel $175 \mathrm{mg} / \mathrm{m}^{2}$ ), and they did not perform radiotherapy.

We used the following exclusion criteria: inflammatory breast cancer, pregnancy, history of hypersensitivity to patent blue, prior axillary surgery or incisional biopsy that compromises the lymphatic drainage of the breast and clinically positive axilla after chemotherapy.

Application has been submitted for approval of this research by the Research Ethics Committee of the Maternity School Assis Chateaubriand under number 75/06 and approved by them as office number 022/07.

Confirmed the histological diagnosis of breast cancer, and these being carriers of locally advanced disease, neoadjuvant chemotherapy was indicated using the scheme of polychemotherapy. After completion of each chemotherapy cycle, patients were examined with the aim to observe their clinical response, evaluating the reduction of the tumor and the axillary status.

The chosen patients were submitted to surgical procedure. After general anesthesia it was performed administration of one (01) vial of patent blue $\mathrm{V}(50 \mathrm{mg} / \mathrm{ml})$ in volume of $02 \mathrm{ml}$ of sodium salt of patent blue $\mathrm{V}$, injectable solution, in the subareolar region affected breast; this procedure was performed intraoperatively, 
two minutes before the incision. Gentle massage was performed at the site of injection for five minutes. All patients underwent sentinel lymph node biopsy through an incision in the anterior fold of the axilla.

After identifying the blue lymphatic channels, it was dissected until sentinel lymph node visualization. The sentinel lymph node was classified as assumed the blue color by dye uptake. Once the sentinel node was excised, it was sent for examination intra-operatively in order to evaluate their metastatic involvement by neoplastic cells.

All patients were submitted to complete axillary dissection, and its product was sent for histological study with the technique of paraffin. The non-sentinel lymph nodes were sectioned into two parts and evaluated for the presence or absence of metastases, with the purpose of comparison with the LS.

After surgery, patients were referred for workup previously scheduled (adjuvant chemotherapy, radiotherapy and hormone therapy, if indicated).

\section{Results}

From 34 patients who fulfilled the inclusion criteria for the study, ages ranged from 29-72 years (48.3 years on average). Most patients had tumor size between 5.1 to $6.0 \mathrm{~cm}$ (10 patients), and patients with $\mathrm{T} 4 \mathrm{~b}$ represented $29.4 \%$. At baseline, $70.6 \%$ of patients had clinically positive axilla and $29.4 \%$ were clinically negative. The chemotherapy regimen more used was FAC and it was applied in $50 \%$ of patients, followed by the AC, in $29.4 \%$ of cases (Table 1).

TABLE 1 - Characteristics of patients.

\begin{tabular}{|c|c|c|}
\hline & $\mathrm{N}$ & $\%$ \\
\hline \multicolumn{3}{|l|}{ Tumor Stage } \\
\hline $\mathrm{T} 2$ & 9 & 26.5 \\
\hline $\mathrm{T} 3$ & 14 & 41.2 \\
\hline $\mathrm{T} 4 \mathrm{a}$ & 1 & 2.9 \\
\hline $\mathrm{T} 4 \mathrm{~b}$ & 10 & 29.4 \\
\hline \multicolumn{3}{|l|}{ Axillary Stage } \\
\hline N0 & 10 & 29.4 \\
\hline $\mathrm{N} 1$ & 23 & 67.6 \\
\hline $\mathrm{N} 2$ & 1 & 3 \\
\hline \multicolumn{3}{|l|}{ Chemoterapy regimen } \\
\hline $\mathrm{AC}$ & 10 & 29.4 \\
\hline FAC & 17 & 50 \\
\hline FAC e paclitaxel & 2 & 5.8 \\
\hline FEC & 2 & 5.9 \\
\hline FEC e paclitaxel & 3 & 8.9 \\
\hline Total & 34 & 100 \\
\hline
\end{tabular}

The mastectomy was the procedure most often used in $97.1 \%$ of cases. All patients were submitted to sentinel node biopsy using patent blue dye as marker and it was found an identification rate of $85.3 \%$ (Table 2 ).

TABLE 2 - Frequency distribution and percentage of patients according to the sentinel lymph node (identified and unidentified) and non-sentinel lymph node.

\begin{tabular}{ccc}
\hline & $\mathrm{N}$ & $\%$ \\
\hline Sentinel node involvement & & \\
Identified & 29 & 85.3 \\
Unidentified & 5 & 14.7 \\
Total & 34 & 100 \\
& & \\
Non-sentinel node involvement & & \\
Negative & 19 & 55.9 \\
Positive & 15 & 44.1 \\
Total & 34 & 100
\end{tabular}

For the contents of axillary dissection, it was found the number of lymph nodes between 7 to 27 . The average number of axillary lymph nodes recovered was 16.4 . The content analysis of axillary dissection showed that $44.1 \%$ of lymph nodes were positive for cancer (Table 2).

In the test of paraffin and imprint of sentinel lymph nodes compared with the gold standard (study of the content of axillary dissection) it was observed that the test imprint + paraffin had sensitivity and specificity respectively equal to $84.62 \%$ and $100,0 \%$. There were $47.0 \%$ of patients with positive nodes in this population. It was estimated that the false-negative rate was $12.01 \%$ and false-positive rate, $0 \%$. The accuracy of the imprint + paraffin was estimated at $92.77 \%$. In patients with negative lymph nodes, the chance of a negative diagnosis by sentinel lymph node biopsy technique is 6.5 times higher than of having the same diagnosis in patients with positive lymph nodes.

\section{Discussion}

There has been controversy in the literature regarding the influence of age on the rate of SLN identification with some studies suggesting an inverse relationship. The mean age group in this study was 48.3 years (29-72 years). There was no difference in identification of sentinel lymph node according to age. Studies by Shen et al..$^{7}$ and Kinoshita et al. ${ }^{8}$ included average age of 49 and 51.1 years respectively.

Most patients had tumors above five centimeters or skin infiltrating tumors then classified as locally advanced (73.5\%). The 
tumor staging after chemotherapy did not alter the rate of sentinel lymph node identification. Regarding the staging, the findings are similar to those found in India, which show $50 \%$ to $70 \%$ of all cancers represented by locally advanced disease, while in most developed countries the tumors are found at early stages ${ }^{9}$.

Several markers have been tested for SLN identification. The most famous are the patent blue and radiocolloid. The rate of SLN identification using only the blue dye was $85.3 \%$. Higher series are found using data from patients who not undergo to neoadjuvant chemotherapy as can be seen in the study of sentinel lymph node biopsy performed by Mc Masters et al. ${ }^{10}$ in which 806 patients were studied obtaining identification rate of $86 \%$. Xing et al. ${ }^{11}$ and Shen et al. ${ }^{13}$ used patients who had undergone chemotherapy and the rate of sentinel lymph node identification was $91 \%$ and $92.8 \%$ using blue dye and radiocolloid concurrently. In the multicenter study by Mamounas et al. ${ }^{14,16}$, the rate of identification of sentinel lymph node was demonstrated over $90 \%$, with $8.4 \%$ of false negative.

When we studied the histology of the contents of the axillary dissection, the average number of lymph nodes identified was 16.4 with a diagnosis of lymph nodes positive for cancer in $47.1 \%$ of patients. Important differences in the groups studied have brought different rates of positive lymph nodes as in the study described by Giuliano et al..$^{12}$, which evaluated 751 lymph nodes, among which 688 non-sentinel lymph nodes, with positive findings in $13.5 \%$. This number differs greatly from the findings of our work because $59.8 \%$ of the patients described by Giuliano et $a l .{ }^{17}$ suffered from $\mathrm{T} 1$ and $\mathrm{T} 2$ tumors, providing a positive histological status of the axilla in only $35.6 \%$ of patients. It is known that lymph node involvement provides a decline in survival with the increase of number of lymph nodes ${ }^{13}$.

The imprint and paraffin in sentinel lymph nodes identified when compared to the gold standard (study of paraffin from the axillary dissection) had a sensitivity of $84.62 \%$, proving to be insufficient to be indicated separately.

The results can be explained partly by the sample number. Series with small sample sizes have found highly variable results. However, most studies had small numbers of patients and variable rates of false-negative. In the small serie reported by Nason et $a l .{ }^{17}$, sentinel lymph node biopsy showed false negative of $33 \%$ with unacceptable accuracy. The same can be observed in the study of Julian et al. ${ }^{18}$.

The variability in the effectiveness and accuracy of sentinel node biopsy after neoadjuvant chemotherapy corroborate the need to evaluate the approach in larger series. The sentinel lymph node biopsy after neoadjuvant chemotherapy is technically feasible. Such treatment, however, can eradicate outbreaks of disease in axillary lymph nodes, and clinical significance of these negative findings is not clear in the long term.

\section{Conclusion}

The study using intraoperative cytology and paraffin analysis of sentinel lymph node in patients with locally advanced breast cancer who underwent neoadjuvant chemotherapy should not be recommended according to data from the sample given the high rate of false-negative reported in the study requiring additional study with larger series to validate the method.

\section{References}

1. Instituto Nacional do Câncer (INCA). Câncer de mama. Disponível em http://www.inca.gov.br/conteudo_view.asp?Id=336.

2. Instituto Nacional do Câncer (INCA). Síntese de resultados e comentários: câncer de mama. Disponível em http://www.inca.gov. br/estimativa/2006/index.asp?Link=conteudo_view.asp\&id=5.

3. Pessoa EC, Rodrigues JR, Michelin O, de Luca HV, Kamiya CP, Traiman P, Uemura G. Avaliação da resposta à quimioterapia primária em amostra de mulheres brasileiras com tumores de mama localmente avançados. Rev Bras Ginecol Obstet. 2007;29(1):18-26.

4. Hsueh EC, Turner RR, Glass EC, Brenner RJ, Brennan MB, Giuliano AE. Sentinel node biopsy in breast cancer. J Am Coll Surg. 1999;189:207-13.

5. Fisher B, Bryant J, Wolmark N, Mamounas E, Brown A, Fisher ER, Wickerham DL, Begovic M, DeCillis A, Robidoux A, Margolese RG, Cruz AB Jr, Hoehn JL, Lees AW, Dimitrov NV, Bear HD. Effect of preoperative chemotherapy on the outcome of women with operable breast cancer. J Clin Oncol. 1998;16(8):2672-85.

6. Anderson B. Pathologic response to preoperative systemic therapy: the new biological paradigm for predicting outcome and planning therapy. Ann Surg Oncol. 2003;10(7):713-5.

7. Shen J, Gilcrease MZ, Babiera GV, Ross MI, Meric-Bernstam F, Feig BW, Kuerer HM, Francis A, Ames FC, Hunt KK. Feasibility and accuracy of sentinel lymph node biopsy after preoperative chemotherapy in breast cancer patients with documented axillary metastases. Cancer. 2007;109(07):1255-63.

8. Kinoshita T, Takasugi M, Iwamoto E, Akashi-Tanaka S, Fukutomi $\mathrm{T}$, Terui S. Sentinel lymph node biopsy examination for breast cancer patients with clinically negative axillary lymph nodes after neoadjuvant chemotherapy. Am J Surg. 2006;191:225-9.

9. Volm M, Formenti S. Treatment of locally advanced breast cancer. Breast Cancer. 2005;20:567-73.

10. McMasters KM, Tuttle TM, Carlson DJ, Brown CM, Noyes RD, Glaser RL, Vennekotter DJ, Turk PS, Tate PS, Sardi A, Cerrito PB, Edwards MJ. Sentinel lymph node biopsy for breast cancer: a suitable alternative to routine axillary dissection in muitiinstitudtional practice when optimal technique is used. J Clin Oncol. 2000;18(13):2560-6.

11. Xing Y, Cormier JN, Kuerer HM, Hunt KK. Sentinel lymphnode biopsy following neoadjuvant chemotherapy: review of the literature and recommendations for use in patient management. Asian J Surg. 2004;27(4):262-7.

12. Giuliano AE. Mapping a pathway for axillary staging: a personal perspective on the current status of sentinel lymph node dissection 
for breast cancer. Arch Surg. 1999;134:195-9.

13. Carter CL, Allen C, Henson DE. Relation of tumor size, lymph node status, and survival in 24,740 breast cancer cases. Cancer. 1989;163(1):181-7.

14. Mamounas EP. Sentinel lymph node biopsy after neoadjuvant systemic therapy. Surg Clin North Am. 2003;83:931-42.

15. Fisher B, Brown A, Mamounas E, Wieand S, Robidoux A, Margolese RG, Cruz AB Jr, Fisher ER, Wickerham DL, Wolmark N, DeCillis A, Hoehn JL, Lees AW, Dimitrov NV. Effect of preoperative chemotherapy of local regional disease in women with operable breast cancer: findings from national surgical adjuvant breast and bowel project b-18. J Clin Oncol. 1997;15:2483-93.

16. Mamounas EP, Brown A, Anderson S, Smith R, Julian T, Miller B, Bear HD, Caldwell CB, Walker AP, Mikkelson WM, Stauffer JS, Robidoux A, Theoret H, Soran A, Fisher B, Wickerham DL, Wolmark N. Sentinel node biopsy after neoadjuvant chemotherapy in breast cancer: results from national surgical adjuvant breast cancer and bowel project protocol b-27. J Clin Oncol. 2005;23:2694-5.

17. Nason KS, Anderson BO, Byrd DR, Dunnwald LK, Eary JF, Mankoff DA, Livingston R, Schmidt RA, Jewell KD, Yeung RS, Moe RE. Increased false negative sentinel node biopsy rates after preoperative chenotherapy for invasive breast carcinoma. Cancer. 2000;89:2187-94.

18. Julian TB, Patel N, Dusi D. Sentinel lymph node biopsy after neoadjuvant chemotherapy for breast cancer. Am J Surg. 2001;182:407-10.

\section{Correspondence:}

Luiz Gonzaga Porto Pinheiro

Departamento de Cirurgia

Rua Prof. Costa Mendes, $1608 / 3^{\circ}$ andar

60430-140 Fortaleza - CE Brasil

Tel.: (55 85)3366-8063

Fax: (55 85)3283-7851

luizgporto@uol.com.br

Received: July 20, 2012

Review: September 19, 2012

Accepted: October 18, 2012

Conflict of interest: none

Financial support: none

${ }^{1}$ Research performed at Department of Mastology, Walter Cantidio University Hospital and Assis Chateaubriand Maternity School, Federal University of Ceara (UFC), Fortaleza, Brazil. 